\title{
Correlates the Biochemical Markers of Ovarian Neoplasm, Experience From A Tertiary Care Setting in A City Of India.
}

\author{
Dr. Sukla Nath ${ }^{1}$,Dr. Mallika Biswas ${ }^{1}$,Dr. Swati Bhattacharyya ${ }^{2}$, \\ Dr. Tarun Biswas \\ ${ }^{\text {I}(B i o c h e m i s t r y, ~ N . R . S ~ M e d i c a l ~ C o l l e g e / ~ W e s t ~ B e n g a l ~ U n i v e r s i t y ~ O f ~ H e a l t h ~ S c i e n c e s, ~ I n d i a) ~}$ \\ ${ }_{2}^{2}$ (Biochemistry, North Bengal Medical College/ West Bengal University Of Health Sciences, India) \\ 3 (Pharmacology, Midnapore Medical College/ West Bengal University Of Health Sciences, India)
}

\begin{abstract}
Most ovarian neoplasms are benign, epithelial types are commonest. There is no regular screening test for detecting malignant ovarian neoplasm, most patients remain asymptomatic until late stages. About $80 \%$ of malignant ovarian neoplasm present in stage 3 and 4 with 15\% 5 year survival rate.

To find out frequency of different types of ovarian neoplasm among women aged 15-60 years and correlates ovarian neoplasm among benign and malignant neoplasms and compare levels of tumour markers among subjects with benign and malignant neoplasms.

A Cross sectional descriptive study conducted in a tertiary care setting, city of Eastern India, women aged 15 60 years with ovarian neoplasm. 131 selected study subjects interviewed with predesigned schedule, levels of tumour markers CA-125 and $\beta$-hCG estimated. Final analysis done on 112 histopathologically confirmed cases. Data analyzed in SPSS version 16.0.

Most ovarian neoplasms were benign (65\%). Histopathologically commonest serous cyst adenoma (25\%), serous cyst adenocarcinoma (23.22\%). Malignant neoplasm had significant association with urban residence (56.41\%) ( $p=0.048)$, menopause $(53.84 \%) \quad(p=0.005)$ and serum $C A-125(p=0.0001)$. Patients with gynaecological comorbidities found suffering more benign ovarian neoplasm $(p=0.01)$.

Postmenopausal women have more chance of having malignant ovarian neoplasm than benign neoplasm.
\end{abstract}

Keywords : CA-125, menopause, ovarian neoplasm, tumour markers

\section{Introduction}

Structure of ovary differs in its embryological, histological \& steroidogenesis aspects. Therefore ovarian neoplasm shows a wide variation in structure \& biological behavior. These neoplasms are mostly benign, only small percentage of these turn to malignancy [1]. In India ovarian neoplasm comprise about 5\% of all types of gynaecological neoplasm and remain asymptomatic or presents with non-specific signs and symptoms [2]. But unlike cervix \& uterus the ovaries are not clinically accessible. Therefore no easy screening method is available to detect it at early stage [1-3].

Malignant neoplasms are very aggressive and fatal. Data from various sources reveal that ovarian cancer can shorten the life span by an average of 18 years [4]. The low survival rate is largely attributed to the fact that most cases remain undiagnosed until the disease has progressed to an advanced stage [5]. Despite high (90-95\%) 5 years survival rate of stage 1 neoplasm, only $20 \%$ of the same comes to noticed [6]. Women with higher age are at highest risk. More than half the deaths from ovarian cancer occur in women between 55 and 74 years of age and approximately one quarter of such deaths occur in women between 35 and 54 years of age [7].

The risk of developing ovarian cancer includes epidemiologic, environmental, and genetic factors [1]. It is notably higher among affluent society and in highly industrialized countries [2]. Overall, $90 \%$ of tumors are benign, although they are more likely to be malignant in the older women. The most common solid tumor in younger women is the cystic teratoma, also commonly known as a dermoid. Epithelial cell tumors are more common among older women. Benign neoplasms are often asymptomatic, but they can present with pain, abdominal swelling, pressure effects, menstrual disturbances or hormonal effects. Bimanual examination usually reveals a mass in the pelvis, and it may be possible to assess the mobility, consistency, and tenderness of the mass and the presence of nodules in the pouch of Douglas. A hard irregular fixed mass with ascites suggests malignancy [8]. However, screening of this tumour currently not recommended outside of a clinical trial and routine yearly rectovaginal pelvic examination does not have enough sensitivity to diagnose early disease [9].

The most widely used tumor marker in ovarian cancer is CA-125 [10]. It was first identified by Bast, Knapp, and colleagues [11]. CA-125 is a high molecular weight nitroglycerin which is raised in approximately $90 \%$ of patients with advanced epithelial ovarian cancer [12]. Human choice namedropping (hCG) the so-called pregnancy hormone is secreted by the claustrophobic cells of normal placenta. $\beta$-hCG levels are increased in pregnancy, trophoblastic diseases and germ cell tumors. Some amount of elevation also found in melanoma, 
carcinoma of breast, gastrointestinal tract, lung, and ovary and in benign condition like cirrhosis, duodenal ulcer and inflammatory bowel disease [13].

This study was undertaken to find out the frequency of the different types of ovarian neoplasm among women admitted in the gynecology inpatient department in the age group of 15 to 60 years and to determine its correlates among them and to compare the levels of tumour markers among the subjects with benign and malignant neoplasms.

\section{Materials And Methods}

This descriptive, cross sectional study was conducted in the department of Biochemistry in liaison with the Department of Gynecology and Obstetrics, Pathology and Community Medicine of R. G. Kar Medical College, Kolkata, India following approval from the institutional Ethics Committee. This is a tertiary care hospital catering to a huge patient load from the city as well as the adjoining districts. The study was carried out from August 2011- July 2012 among women with in the age bracket of 15-60 years with sonologically diagnosed new cases of primary ovarian neoplasm admitted to the Gynecology inpatient department for surgical intervention. The study subjects were selected based on predefined inclusion and exclusion criteria incorporating all eligible subjects during the study period. Pregnancy, metastatic ovarian neoplasm, ovarian neoplasm with history of radiotherapy and chemotherapy were set as exclusion criteria.

Thus out of 138 admissions in that year 131 subjects could be included in the study. Data on demographic and relevant biological variables were collected in a predesigned pretested schedule by interviewing the study participants with prior informed consent. Biochemical investigation for tumour markers like CA-125, $\beta$-hCG levels were measured drawing preoperative blood sample. For accurate comparison, a fasting venous blood sample was taken as specimen and sera was stored in $\left(-20^{\circ} \mathrm{c}\right)$ in aliquots before analysis of CA-125 and $\beta$-hCG. Estimation of serum CA-125 level was carried out by Enzyme linked immune sorbent assay (ELISA) method. Instrument used was ELISA reader with automatic washer of Robonik-Read well touch). Kits were obtained from MONOBIND INC, LAKE FOREST, CA 92630, USA, Through Lilac Medicare (P) Ltd. Chemicals. Estimation of serum $\beta$-hCG level was carried out by Enzyme linked immune sorbent assay (ELISA) method. Chorionic Gonadotropin ( $\beta$-hCG) Kit was obtained from MONOBIND INC.LAKE FOREST, CA 92630, USA through Lilac Medicare (P) Ltd. All chemicals used for various estimations were of analytical grade. The ultimate classification of tumour as benign or malignant was done by post-operative histopathological examination of the tissues by the Department of pathology and only confirmed cases were included in the analysis. The data were analyzed using SPSS version 16.0 under the guidance of Department of Community Medicine using descriptive statistics and inferential statistics. Chi-square test and fisher exact test and Mann-Whitney U test were used, odds Ratio, 95\% were also calculated. Levels of significance ware assumed at $\mathrm{p}$ value $<0.05$ with confidence interval.

\section{Results}

Thus in this study out of 131 subjects 112 were considered in the final analysis. Among 112 cases, 73 $(65.1 \%)$ were benign and $39(34.9 \%)$ were having malignant tumour. In this study the commonest neoplasm was Serous cyst adenoma (25\%) followed by serous cyst adenocarcinoma (23.4\%). Benign teratoma and Mucinous cyst adenoma were $23(20.54 \%)$ and $10(8.93 \%)$ respectively and Mucinous cyst adenocarcinoma were $8(7.15 \%)$ see "Fig"-1. The distribution of CA-125 and $\beta$-hCG were found to be nonparametric and thus the mean ranks were compared using Mann-Whitney U test. CA -125 has significant association with the malignant neoplasm. The level of CA-125 was noted to be significantly higher among those with malignant neoplasm and serous carcinoma compared to benign and non-serous CA respectively. $\beta$-hCG has no significant relation with the type of neoplasm.

\section{Discussion}

Ovarian neoplasms are benign and malignant tumour. Cancer of the ovary is one of the most common cancers amongst females and it ranked third/fourth among cancers occurring in women during the year 200405 amongst various Indian registries. During the period 2001-06, the age-standardized incidence rates (ASR) for ovarian cancer varied from 0.9 to 8.4 per 100,000 person years amongst various registries. The highest incidence was noted in Pune \& Delhi registries. Increased incidence may be due to increased life expectancy leading to increase in proportion of elderly persons [14]. In the present study we observed a preponderance of malignancy in higher age group.

In this study total numbers of ovarian neoplasm patients were 112 . Out of 112 tumour patients 73 $(65 \%)$ were benign and $39(35 \%)$ were malignant cases. Among the benign neoplasm serous cyst adenoma $(25 \%)$ was most common followed by benign teratoma $(20.54 \%)$ and mucinous cyst adenoma (10\%). Serous cyst adenocarcinoma (23.22\%) was the most common malignant neoplasm followed by mucinous cyst adenocarcinoma $(7.15 \%)$. Other malignant tumour were $2(1.78 \%)$ cases of immature teratoma along with single 
cases of Clear cell, embryonal, and transitional cell carcinoma were found see "Fig"-1. The findings of Mondal et al study support this observation [15]. In their study (63.1\%) were benign tumors followed by malignant (29.6\%) and borderline tumors (7.3\%) and most common histological types were serous cystadenoma (29.9\%), mature teratoma $(15.9 \%)$ and mucinous cystadenoma $(11.1 \%)$. Serous cyst adenocarcinoma and mucinous carcinoma were $11.3 \%$ and $3.3 \%$ respectively [15]. Our observation is similar with the study of V. Thakur et al. In their study out of 40 malignant subjects, most common type was papillary serous adenocarcinoma (82.5\%) followed by mucinous adenocarcinoma (10.0\%). Two had endometrioid carcinoma (5.0\%) and only one patient was reported to have clear cell carcinoma (2.5\%) [16]. Ovarian malignancy was more in industrialized countries and urban population [2]. In present study urban population were more affected with malignant neoplasms. (refer table-3). This observation is supported by N.S .Murthy et al1 [4]. Though etiology of ovarian cancer is poorly understood but there are different studies showing urban population and menopausal women are at increased risk of developing malignant ovarian neoplasm.

Malignant tumour was more common in postmenopausal women than benign tumour. Among the 39 malignant tumour patients $18(46.16 \%)$ were postmenopausal and $21(53.84 \%)$ were premenopausal women. In the benign group, out of 73 patients $20(27.40 \%)$ were postmenopausal and $53(72.60 \%)$ premenopausal women. Malignant ovarian neoplasm were significantly more in postmenopausal women $(\mathrm{p}=0.005)($ table-2). This findings agrees with the observation of Cannistra S A. et al [17] In our study benign neoplasm had significant association $(\mathrm{p}=0.01)$ with other gynaecological diseases. As the number of study subjects was few, it requires further study on large population before we comment on this. Patient having some symptomatic gynaecological disease seek medical advice earlier and comes in follow up visit, so it may happen that neoplasm at benign condition comes to notice. The tumour marker CA-125 is a glycoprotein synthesized by ovarian superficial cells; its serum measurement has an established role in monitoring treatment and detecting recurrence of ovarian cancer and has been advocated as a prognostic marker for advanced ovarian cancer [18-19]. Serum CA-125 was significantly correlated $(\mathrm{p}=0.0001)$ with malignant neoplasm. This is agreeing with the observation of $\mathrm{K}$. K. Zorn et al [20]. Daniel W Cramer.et al also mentioned similar observation in their study [21].

There was significant $(\mathrm{p}=0.001)$ difference in serum CA-125 level between serous carcinoma and nonserous carcinoma in our study. There are studies showing that elevated levels of CA-125 are more strongly associated with serous, rather than mucinous tumors [22]. In our study serum levels of $\beta$-hCG had no significant relation but few other studies have showed that $\beta$-hCG has no reliable diagnostic value in ovarian cancer [23]. Present study showed no significant relation between parity and occurrence of malignancy, family history of gynaecological neoplasm had no significant association with malignant neoplasm. As our sample size was small, a study on a large population is needed to be done in the future to more conclusively determine the association of different factors with ovarian neoplasm.

\section{Figures And Table}

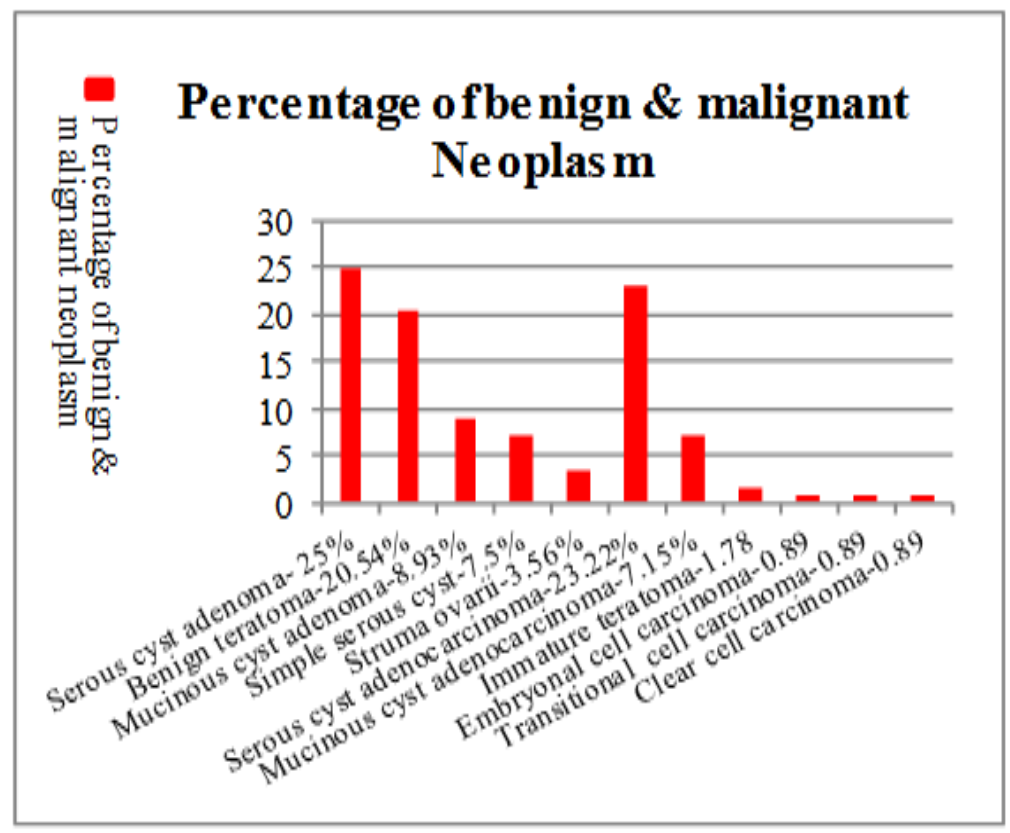

Figure - 1. Percentage of benign \& malignant neoplasm 
Table No. 1: Distribution Of Different Types Of Neoplasm Among The Study Subjects (N=112)

\begin{tabular}{|l|c|c|}
\hline Types of Neoplasm & No & Percentage \\
\hline Benign $(\mathbf{n}=\mathbf{7 3})$ & 28 & 25 \\
1. Serous cyst adenoma & 23 & 20.54 \\
2. Benign teratoma & 10 & 8.93 \\
3. Mucinous cyst adenoma & 8 & 7.15 \\
4. Simple serous cyst & 4 & 3.56 \\
5. Struma ovarii & 26 & 23.22 \\
\hline Malignant (n=39) & 8 & 7.15 \\
1.Serous cyst adenocarcinoma & 2 & 1.78 \\
2. Mucinous cyst adenocarcima & 1 & 0.89 \\
3. Immature teratoma & 1 & 0.89 \\
4. Embryonal cell carcinoma & 1 & 0.89 \\
5. Transitional cell carcinoma & 112 & 100 \\
6. Clear cell carcinoma & \multicolumn{1}{|c|}{ Total } &
\end{tabular}

Table No.2: Correlates of Ovarian neoplasm $(\mathrm{N}=112)$

\begin{tabular}{|c|c|c|c|c|}
\hline Correlate & $\begin{array}{l}\text { Benign }(n=73) \\
\text { No. }(\%)\end{array}$ & $\begin{array}{l}\text { Malignant } \\
(\mathbf{n}=39) \quad \text { No. } \\
(\%)\end{array}$ & Significance & OR $(95 \% \mathrm{CI})^{*}$ \\
\hline $\begin{array}{ll}\text { Age(in years) } & 45-60(\mathrm{n} 2=47) \\
15-45(\mathrm{n} 1=65)\end{array}$ & $\begin{array}{l}49(67.12 \%) \\
24(32.88 \%)\end{array}$ & $\begin{array}{l}16(41.02 \%) \\
23(58.98 \%)\end{array}$ & $\chi^{2}=7.11, p=0.007$ & $2.93(1.22-7.11)$ \\
\hline $\begin{array}{r}\text { Urban }(\mathrm{n} 1=63) \\
\operatorname{Rural}(\mathrm{n} 2=49)\end{array}$ & $\begin{array}{l}46(63.01 \%) \\
27(36.99 \%)\end{array}$ & $\begin{array}{l}17(43.59 \%) \\
22(56.41 \%)\end{array}$ & $\chi^{2}=3.90, p=0.048$ & $2.2(0.93-5.26)$ \\
\hline $\begin{array}{l}\text { Marital status } \\
\text { Current/Newer married(n1=101) } \\
\text { Never married(n2=11) }\end{array}$ & $\begin{array}{l}65(89.04 \%) \\
8(10.96 \%)\end{array}$ & $\begin{array}{l}36(92.30 \%) \\
3(7.70 \%)\end{array}$ & $\begin{array}{l}\mathrm{P}=0.74 \text { (Fischer } \\
\text { exact, two tailed) }\end{array}$ & $0.68(0.13-3.07)$ \\
\hline $\begin{array}{r}\text { Nulliparous }(\mathrm{n} 1=18) \\
\text { Parous }(\mathrm{n} 2=94)\end{array}$ & $\begin{array}{l}13(17.80 \%) \\
60(82.20 \%)\end{array}$ & $\begin{array}{l}5(12.82 \%) \\
34(87.18 \%)\end{array}$ & $\chi^{2}=0.47, p=0.49$ & $1.47(0.44-5.22)$ \\
\hline $\begin{array}{l}\text { Menopausal status } \\
\text { Post-menopausal(n1=41) } \\
\text { Menstruating (n2=71) }\end{array}$ & $\begin{array}{l}20(27.40 \%) \\
53(72.60 \%)\end{array}$ & $\begin{array}{l}21(53.84 \%) \\
18(46.16 \%)\end{array}$ & $\begin{array}{l}\chi^{2}=7.66 \\
\mathrm{p}=0.005\end{array}$ & $3.09(1.27-7.58)$ \\
\hline $\begin{array}{l}\text { Family history of Present }(\mathrm{n} 1=12) \\
\text { Gynaecological Absent }(\mathrm{n} 2=100) \\
\text { neoplasm }\end{array}$ & $\begin{array}{l}9(12.32 \%) \\
64(87.68 \%)\end{array}$ & $\begin{array}{l}3(7.69 \%) \\
36(92.31 \%)\end{array}$ & $\begin{array}{l}\mathrm{P}=0.53 \text { (Fischer } \\
\text { exact, two tailed) }\end{array}$ & $1.69(0.38-8.45)$ \\
\hline $\begin{array}{ll}\begin{array}{l}\text { History of } \\
\text { gynaecological }\end{array} & \text { Present }(\mathrm{n} 1=27) \\
\text { comorbidity } & \text { Ablent }(\mathrm{n} 2=85)\end{array}$ & $\begin{array}{l}23(31.50 \%) \\
50(68.50 \%)\end{array}$ & $\begin{array}{l}4(10.25 \%) \\
35(89.75 \%)\end{array}$ & $\chi^{2}=6.27, \mathrm{p}=0.01$ & $\begin{array}{l}4.03(1.17- \\
15.14)\end{array}$ \\
\hline
\end{tabular}

$\mathrm{OR}=$ Odds ratio, $\mathrm{CI}=$ Confidence interval, $\mathrm{n}=$ number of patients

Table No.3: Comparison of the levels of tumour markers in subjects with benign and malignant ovarian

\begin{tabular}{|l|l|l|l|l|}
\hline $\begin{array}{l}\text { Tumour } \\
\text { markers }\end{array}$ & Types of neoplasm & Mean Rank & Median & $\begin{array}{l}\text { Mann-Whitney } \\
\text { (Significance) }\end{array}$ \\
\hline CA-125 & Benign $\left(\mathrm{n}_{1}=73\right)$ & 38.43 & 15 & $104.500(0.000)$ \\
\hline & Malignant $\left(\mathrm{n}_{2}=39\right)$ & 90.32 & 165 & \\
\hline & Serous carcinoma $\left(\mathrm{n}_{1}=26\right)$ & 25.12 & 568.5 & $36.000(0.000)$ \\
\hline & Non serous carcinoma( $\left.\mathrm{n}_{2}=13\right)$ & 9.77 & 62 & \\
\hline$\square$-HCG & Benign $\left(\mathrm{n}_{1}=73\right)$ & 55.21 & 2.67 & $1329.000(0.564)$ \\
\hline & Malignant $\left(\mathrm{n}_{2}=39\right.$ & 58.92 & 2.11 & \\
\hline
\end{tabular}

\section{Conclusionc}

So, to conclude, the present study shows significant association of urban residence, menopause and serum CA-125 levels with malignant ovarian neoplasm. Other gynaecological disorders were found to have significant association with benign neoplasm.

\section{Acknowledgements}

We thank all the doctors and staffs of department of gynecology and obstetrics, Pathology and Biochemistry and all the patients who participated in the study. 


\section{References}

[1]. Robert CY, Gynaecologic Malignancies, in Dan L, Longo, Dennis L. Kasper, J. Larry Jameson, Anthony S. Fauci, Stephen L. Hauser, Joseph Loscalzo, Harrison's principles of internal medicine, 17 (New York: Mc Graw Hill, 2012 ) $810-812$.

[2]. Padubidri V G, Daftary SN, Howkins and Bourne, Shaw`s text book of gynaecology ( New Delhi: Elsevier, 2004) 354-372.

[3]. Keith D, Edmonds, Mohaghan, J M, Dewhurst`s Text book of obstetrics \& gynaecology (London: Blackwell, 1999) 590-593.

[4]. Fields MM, Chevlen E, Ovarian cancer screening: a look at the evidence, Clinical Journal of Oncology Nursing. 10(1), 2006, 7781.

[5]. Van Nagell JR Jr, DePriest PD, Ueland FR, DeSimone CP, Cooper AL, McDonald JM, Ovarian cancer screening with annual transvaginal sonography: findings of 25,000 women screened. Cancer, 109(9), 2007, 1887-1895.

[6]. Mani R, Jamil K, Specificity of Serum Tumor Markers (CA125, CEA, AFP, Beta HCG) in Ovarian Malignancies, Trends in Medical Research, 2, 2007, 128-134.

[7]. Bryan T. H, Grace K. S, Maurie M, Ovarian Cancer, in Hagop M. K, Robert A. W, Charles A. K, The MD Anderson Manual of Medical Oncology, 28 (New York: McGraw-Hill, 2011)

[8]. Norwitz, Errol R, Arulkumaran, Symonds S, Fowlie I. M, Oxford American Handbook of Obstetrics and Gynecology (New York: Oxford University, 2007)

[9]. Joel L, Ginger J.G, Ovarian Cancer, in Fortner, Kimberly B, Szymanski, Linda M, Fox, Harold E, Johns hopkins manual of gynecology and obstetrics, (Baltimore, Maryland: Lippincott Williams \& Wilkins, 2007) 510-525.

[10]. Hogdall E, Cancer antigen 125 and prognosis, Current Opinion in Obstetrics and Gynecology, 20, 2008, 4-8.

[11]. Bast RC, Jr, Feeney M, Lazarus H, Nadler LM, Colvin RB, Reactivity of a monoclonal antibody with human ovarian carcinoma, Journal of Clinical Investigation, 68, 1981, 1331-1337.

[12]. Bast RC, Jr, Klug TL, St John E, Jenison E, Niloff JM, A radioimmunoassay using a monoclonal antibody to monitor the course of epithelial ovarian cancer, The New England Journal of Medicine, 309, 1983, 883-887.

[13]. Chan W.D, Booth R. A, Diamandis E.P. Tumor Markers, in Carl A, Burtis, Ashwood E.R, Bruns D.E, Tietz Text book of clinical Chemistry \& Molecular Diagnostics, 4 (St Louis, Missouri, Saunders: Elsevier; 2006) 766.

[14]. Murthy S N, Shalini S, Suman G, Pruthvish S, Mathew A, Changing Trends in Incidence of Ovarian Cancer - the Indian Scenario, Asian Pacific Journal of Cancer Prevention, 10, 2009, 1025-1030.

[15]. Mondal K.S, Banyopadhyay R, Nag R.D, Roychowdhury S, Mondal K.P, Sinha K.S, Histologic pattern, bilaterality and clinical evaluation of 957 ovarian neoplasms: A 10-year study in a tertiary hospital of eastern India, Journal of Cancer Research and Therapeutics, 7(4), 2011, 433-437.

[16]. Thakur V, Anand A.K., Mukherjee U, Ghosh D, Determination of cancer antigen 125 in ovarian carcinoma, Indian Journal of Clinical Biochemistry, 18 (2), 2003, 27-33.

[17]. Maggino T, Gadducci A, D'Addario V, Pecorelli S, Lissoni A, Stella M, Prospective multicenter study on CA 125 in postmenopausal pelvic masses, Gynecologic Oncology, 54, 1994, 117-123.

[18]. Rustin GJ, Nelstrop AE, Tuxen MK, Lambert HE, Defining progression of ovarian carcinoma during follow-up according to CA 125: a North Thames Ovary Group Study, Annals of Oncology, 7, 1996, 361-364.

[19]. Ind H, Ray I, Shephard J, Chard T, Serum concentration of cancer antigen 125, placental alkaline phosphatase, cancer associated serum antigen and free beta human chorionic gonadotrophin as prognostic markers for epithelial ovarian cancer, British Journal of Obstetrics Gynaecology, 104, 1997, 1024-1029.

[20]. Zorn KK, Tian C, McGuire WP, Hoskins WJ, Markman M, Muggia FM, The prognostic value of pretreatment CA 125 in patients with advanced ovarian carcinoma: a Gynecologic Oncology Group study, Cancer, 115(5), 2009, 1028-35.

[21]. Cramer DW, Vitonis AF, Welch WR, Terry KL, Goodman A, Rueda BR, Correlates of the pre-operative level of CA125 at presentation of ovarian cancer, Gynecologic Oncology, 119(3), 2010, 462-468.

[22]. Hogdall EV, Christensen L, Kjaer SK, Blaakaer J, Kjaerbye-Thygesen A, Gayther S, CA125 expression pattern, prognosis and correlation with serum CA125 in ovarian tumor patients. From The Danish "MALOVA" Ovarian Cancer Study, Gynecologic Oncology, 104(3), 2007, 508-515.

[23]. Djurdjevic S, Maksimovic M, Pantelic M, Golubovic A, Curcic A, Usefulness of $\beta$ hCG as tumor marker in the diagnosis and follow up of patients with ovarian cancer, Journal of Balkan Union of Oncology, 16(4), 2011 Oct-Dec, 715-21. 